\title{
Critical Pedagogy and Dialectical Thought in the Secondary English Classroom
}

\section{Daniel Ian Rubin ${ }^{1}$}

In this nation's schools, there must be an increased focus on critical and dialectical thought if there is ever to be any substantive societal change. Due to No Child Left Behind (NCLB) and the increased focus on standardization and uniformity of thought, there has been a move away from critical thinking and the fight for social justice. This paper discusses Marx's notion of dialectical thought and its necessity in the secondary English/Language Arts classroom. This is interwoven with examples of techniques and projects which help students view the world around them in a more critical fashion. [Article copies available for a fee from The Transformative Studies Institute. E-mail address: journal@transformativestudies.org Website: http://www.transformativestudies.org (C2012 by The Transformative Studies Institute. All rights reserved.]

KEYWORDS: Critical Pedagogy, Dialectical Thought, English/Language Arts, Social Justice, Secondary Education.

\section{INTRODUCTION}

In a time of ever-growing disparity between the wealthy and poor, immense political/economic power held by the select few, and

\footnotetext{
${ }^{1}$ Daniel Ian Rubin is a National Board Certified Teacher in English/Language Arts and has been teaching high school English for 14 years. He is a doctoral student at New Mexico State University in Curriculum and Instruction with an emphasis in Critical Pedagogies. He is interested in the intersection of English/Language Arts and critical pedagogy in the secondary classroom. Address correspondence to: Daniel Ian Rubin, New Mexico State University, 2641 Los Misioneros, Las Cruces, New Mexico 88011; email: drubin@nmsu.edu.
} 